Original Article

\title{
Determination of certain growth parameters of cotton (Gossypium barbadense L.) due to Mealy Bug, Phenacoccus solenopsis (Tinsley) infection and endophytic,
}

\section{Beauveria bassiana treatments}

\author{
Mazen A. ${ }^{1}$, Hussen G. ${ }^{2}$, El-Gepaly H. ${ }^{2}$ and Omar M. ${ }^{2}$ \\ ${ }^{1}$ Faculty of Science, Sohag, Sohag University \\ ${ }^{2}$ Plant Protection Research Institute, Agriculture Research Center, Cairo, Egypt. \\ doi:
}

\begin{abstract}
This investigation were carried to test effect of mealy bug infestation and two inoculation methods of the entomopathogenic fungal endophyte, Beauveria bassiana to cotton plant, Gossypium barbadense L. (var. Giza 90) on some chemical component of cotton plant. The change in growth photosynthetic pigment content, total protein content, total antioxidant capacity total flavonoid content and the activities of some antioxidant were determined. Results showed that, $B$. bassiana treatments could induce the length and weight of fresh stem. Pest infestation and/or B. bassiana treatments, an increase in the amounts of flavonoids was noticed as compared to the control while $B$. bassiana application caused decrease in the antioxidant activity of leaf extracts detected by DPPH assay. Cotton plants showed accumulation in total proteins as a defense mechanism against Phenacoccus solenopsis (Tinsley) treatments.
\end{abstract}

KEYWORDS

Endophytes,

Cotton,

Phenacoccus solenopsis,

Beauveria bassiana,

Growth parameters.

CORRESPONDING

AUTHOR

Hosam El-Gepaly

elgepaly@gmail.com

\section{INTRODUCTION}

Egyptian cotton occupies a unique and important role in the world market because it is very high quality, long staple fiber. Cotton is threatened by infestation with many insect pests among which are mealy bugs. Cotton Mealy bug, Phenacoccus solenopsis (Pseudococcidae; Hemiptera) is an exotic pest of several crops especially cotton (Noureen et al. 2016).

Large populations of mealy bugs cause general weakening, defoliation, and death of susceptible plants, mealy bug not only causes direct damage to the host plant by sucking plant sap, but also excretes large quantities of honeydew which encourages the black sooty mold growth and hinders photosynthesis (Arif et al. 2012).
Furthermore, the insect is suspected as vector of plant diseases (Culik \& Gullan, 2005).

Endophytes are micro-organisms colonize and live part of their life cycle within the tissue of a plant as endosymbionts, without causing any disease symptoms (Hardoim et al. 2015; Puri et al. 2016). As well as, preventing colonization of the host by foreign parasitic organisms (Martinuz et al. 2012). Fungal endophytes are utilized as an indirect defense against herbivores (Kim et al., 2007, 2008; Quesada-Moraga et al. 2009).

There are various reports of possible artificial inoculation of plants with fungal entomopathogens to establish as plant endophytes artificially (Gurulingappa et al. 2010; Brownbridge et al. 2012; Parsa et al. 2013; Qayyum et al. 2015; Greenfield et al. 2016). Beauveria bassiana is a 
soil saprophyte, entomopathogen and plant endophyte (Roy et al. 2006; Ownley et al. 2008) Traditionally $B$. bassiana is known as insect pathogens and isolated as naturally occurring endophyte from asymptomatic plant tissues (Bills \& Polishook 1991; Cherry et al. 1999; Vega et al. 2008; Orole \& Adejumo 2009). It is being used as a biological insecticide to control a number of pests. As an endophyte, B. bassiana may play a role in protecting plants from herbivory and disease. Ownley et al. (2008b) reported that endophytic colonization of tomato and cotton seedlings through seed soaking in $B$. bassiana conidia protected the seedlings against biotic factors.

The present study was carried out to test effect of mealy bug infestation and two adding methods of the entomopathogenic fungal endophyte, $B$. bassiana to cotton plant, Gossypium barbadense L. (var. Giza 90) on some chemical component of cotton plant.

\section{MATERIALS AND METHODS}

Plant: Seeds of cotton were obtained from Cotton Research Institute, Agriculture Research Center. Seeds were planted in plastic pots containing of 2 $\mathrm{kg}$ of soil mixture (sand/ peat moss) (1:1) essential nutrient were added.

Fungus: B. bassiana was maintained on PDA medium, (Yong Jia et al. 2013) the fungus can grow in liquid or solid medium as follow in this experiment. Fungal conidia were harvested from 3week-old PDA cultures.

Insects: Phenacoccus solenopsis (Tinsley) were collected from cotton field in Shandaweel research Station, Sohag Governorate. samples were transported and cultured in a laboratory which was maintained on potato tubers with vegetable shoots in a plastic cage $(50 \mathrm{~cm} \times 50 \mathrm{~cm} \times 50 \mathrm{~cm})$ in a climate controlled insectary $\left(18 \pm 2{ }^{\circ} \mathrm{C}, 70 \pm 5 \%\right.$ relative humidity; L16:D8 photoperiod).
Five seeds of cotton were planted in each pot and then irrigated every three days until germination. The best plant was selected for each pot and the rest of the plants were eliminated. Soon after 21 days of germination, seedling pots were arranged in a randomized complete block design (RCBD) with two factors, A: fungus adding methods; spray, watering and without adding (10 pots for each) and B: Each fungal treatment and zero treatment were divided into two parts (5 pots for each), one receiving infection with mealy bugs and the other without infection. $200 \mathrm{ml}$ of the fungus solution were prepared for each treatment (Four flasks, each containing fifty $\mathrm{mm}$ liquid media -previously inoculated with the fungus- were mixed by a mixer) to watering one third of the planting pots, while the solution was used to spray the other third and the fungus was not added to the last third (zero treatment). These treatments were applied every three days for five times and then the addition of fungus was stopped, after that all plants were washed by water, then 5 adults of mealy bugs were used to make an artificial infection to half of pots according to experiment design and infestation development was recorded for 15 days.

\section{Growth parameters}

Germination and growth measurements including fresh weight (FW), dry weight (DW) and stem, root length were recorded.

\section{Plant biochemical analysis}

1. Estimation of photosynthetic pigments: The photosynthetic pigments (Chlorophyll a, Chlorophyll b and Carotenoids) were determined using spectrophotometric method recommended by (Lichtenthaler 1987).

2. Estimation of total protein contents: Total protein contents of leaves were determined at $700 \mathrm{~nm}$, according to Loweryetal (1951) calibration curve was constructed using albumin and the data were expressed as $\mathrm{mg} / \mathrm{g}$ DW. 
3. Determination of total flavonoid contents: Aluminum chloride colorimetric method was used for estimation of total flavonoids (Hegazy et al. 2012; Bhaigyabati et al. 2014).

4. Determination of total antioxidant, DPPH free radical scavenging assay: The free radical-scavenging activity of leaf extract in methanol was measured using the method described by Shimada et al. (1992). The percentage of DPPH scavenging activity was calculated according to Azeez et al. (2012).

\section{DPPH scavenging activity}

$$
=\frac{\text { absorbance of control }- \text { absorbance of test }}{\text { absorbance of control }} \times 100
$$

\section{Statistical analysis}

Data were subjected to analysis of variance (ANOVA) using F-test, followed by calculating the least significant difference (LSD) at $5 \%$ level of probability, using Mstat-C computer-program, to exhibit the differences among all treatments.

\section{RESULTS AND DISCUSSION}

\section{Effect of entophytic $B$. bassiana and mealy bug infestation on growth parameters}

The inoculation of fungi and insect infestation as variable factors were significantly influencing some vegetative and morphological characteristics of the cotton plant as shown in Table (1) Data illustrated that the inoculation with $B$. bassiana in general, led to a significantly increase on average stem length with 41.55 and $42 \mathrm{~cm}$ for spray and watering treatments respectively compared with non-treated by $29.55 \mathrm{~cm}$ (were, LSD= 5.87), data also showed that, spraying treatments were insignificantly lower than watering treatments, however mealy bug infestation has no significant effect. Fresh stem weight not affected by fungus inoculation in general, but un-infested and non-inoculated treatment was decreased significantly gained 4.68 gm (were, LSD = 3.02). In the same table, fresh root length was increased significantly in watering treatment $(35.8 \mathrm{~cm})$ and insignificantly with spraying treatment (28.4) compared with control treatment $(25.85 \mathrm{~cm})$, however, no significantly differences between inoculation methods (LSD = 9.67), in the same time un-infested mealy bug treatments were gained the highest root length by 40.8 and $35.8 \mathrm{~cm}$ for watering and spraying treatments (were, insignificantly among them) and with un-inoculated and watering for mealy buginfested treatments by 31.8 and $30.8 \mathrm{~cm}$ respectively, and significantly differed with fungus spraying insect infested and uninoculated uninfested treatment by 21 and $19.9 \mathrm{~cm}$ respectively (were, $\mathrm{LSD}=13.68$ ). Fresh root weight also was decreased significantly when inoculation B. bassiana by watering ( $2.26 \mathrm{~g})$ compared with spraying and control by $1.38 \mathrm{~g}$ and $1.52 \mathrm{~g}$ respectively (were, $\mathrm{LSD}=0.65$ ), interaction between fungus watering and un-infested treatment record the highest fresh root weight by $3.04 \mathrm{~g}$, while the lowest weight was recorded in un-treated sit by $0.66 \mathrm{~g}$ (were, $\mathrm{LSD}=0.91$ ). With regard to the dry weight of the stems and roots, the uninoculated fungus treatment was achieved the highest dry weight of 5.38 and $0.82 \mathrm{~g}$ followed insignificantly by watering treatments by 3.74 and $0.74 \mathrm{~g}$ and insignificantly differed with control treatment by 1.66 and $0.48 \mathrm{~g}$ respectively.

The literature suggests that genotype specific interactions between plants and entophytes may either enhance, reduce, or have no effect on plant figure (Rodriguez et al. 2009) According to Surendra et al. (2017) used B. bassiana to promote plant growth and had a positive influence on the survival, growth, health, length, and dry weight of cabbage. 
Table (1) fresh and dry parameter affected by mealy bug infestation and B. bassiana inoculation

\begin{tabular}{|c|c|c|c|c|c|c|}
\hline & & Control & Spraying & Watering & $\begin{array}{c}\text { Pest } \\
\text { infestation }\end{array}$ & F\&LSD \\
\hline \multirow{2}{*}{$\begin{array}{l}\text { Fresh stem } \\
\text { length }\end{array}$} & Infested & 30.2 & 39 & 40.5 & 36.57 & \multirow{2}{*}{$0.97 \& 4.79$} \\
\hline & Un-infested & 28.9 & 44.1 & 43.5 & 38.83 & \\
\hline \multicolumn{2}{|c|}{ Fungus inoculation } & 29.55 & 41.55 & 42 & \multirow{2}{*}{\multicolumn{2}{|c|}{$F=0.67 \& 8.3$}} \\
\hline \multicolumn{2}{|l|}{ F\&LSD } & \multicolumn{3}{|c|}{$12.61 \& 5.87$} & & \\
\hline \multirow{2}{*}{$\begin{array}{l}\text { Fresh stem } \\
\text { weight }\end{array}$} & Infested & 11.72 & 11.72 & 7.72 & 10.39 & \multirow{2}{*}{$2.89 \& 3.02$} \\
\hline & Un-infested & 4.68 & 8.42 & 10.68 & 7.93 & \\
\hline \multicolumn{2}{|c|}{ Fungus inoculation } & 8.2 & 10.07 & 9.2 & \multirow{2}{*}{\multicolumn{2}{|c|}{$4.06 \& 5.23$}} \\
\hline \multicolumn{2}{|l|}{ F \& LSD } & \multicolumn{3}{|c|}{$0.56 \& 3.7$} & & \\
\hline \multirow{2}{*}{$\begin{array}{l}\text { Fresh root } \\
\text { length }\end{array}$} & Infested & 31.8 & 21 & 30.8 & 27.87 & \multirow{2}{*}{$1.29 \& 7.9$} \\
\hline & Un-infested & 19.9 & 35.8 & 40.8 & 32.17 & \\
\hline \multicolumn{2}{|c|}{ Fungus inoculation } & 25.85 & 28.4 & 35.8 & \multirow{2}{*}{\multicolumn{2}{|c|}{$4.71 \& 13.68$}} \\
\hline \multicolumn{2}{|l|}{ F \& LSD } & \multicolumn{3}{|c|}{$2.49 \& 9.67$} & & \\
\hline \multirow{2}{*}{$\begin{array}{l}\text { Fresh root } \\
\text { weight }\end{array}$} & Infested & 2.38 & 1.24 & 1.48 & 1.63 & \multirow{2}{*}{$0.18 \& 0.53$} \\
\hline & Un-infested & 0.66 & 1.52 & 3.04 & 1.74 & \\
\hline \multicolumn{2}{|c|}{ Fungus inoculation } & 1.52 & 1.38 & 2.26 & \multirow{2}{*}{\multicolumn{2}{|c|}{$12.53 \& 0.91$}} \\
\hline \multicolumn{2}{|c|}{ F \& LSD } & \multicolumn{3}{|c|}{$5.17 \& 0.65$} & & \\
\hline \multirow{2}{*}{$\begin{array}{l}\text { Dry stem } \\
\text { weight }\end{array}$} & Infested & 5.38 & 3.96 & 3.74 & 4.36 & \multirow{2}{*}{$1.77 \& 1.98$} \\
\hline & Un-infested & 1.66 & 3.68 & 3.96 & 3.1 & \\
\hline \multicolumn{2}{|c|}{ Fungus inoculation } & 3.52 & 3.82 & 3.5 & \multirow{2}{*}{\multicolumn{2}{|c|}{$1.71 \& 3.42$}} \\
\hline \multicolumn{2}{|l|}{ F \& LSD } & \multicolumn{3}{|c|}{$0.05 \& 2.42$} & & \\
\hline \multirow{2}{*}{$\begin{array}{l}\text { Dry root } \\
\text { weight }\end{array}$} & Infested & 0.82 & 0.7 & 0.74 & 0.75 & \multirow{2}{*}{$0.75 \& 0.28$} \\
\hline & Un-infested & 0.48 & 0.9 & 1.22 & 0.87 & \\
\hline \multicolumn{2}{|c|}{ Fungus inoculation } & 0.65 & 0.8 & 0.98 & 20 & 47 \\
\hline F \& LSD & & & $2.13 \& 0.3$ & & 5.54 & 20.47 \\
\hline
\end{tabular}

Effect of endophytic $B$. bassiana inoculation and mealy bug infestation on Chlorophyll a $\& b$ and Carotenoids

Data in Table (2) illustrate the changes in pigments due to fungus inoculation and pest infestation, where chlorophyll a in spraying and watering treatments was slightly decreased than control; Chlorophyll b was decreased than control in two treatments. Carotenoids in watering treatment were slightly decreased than control but in spray slightly increase. Also, pest infestation didn't have significant changes in pigment values. Statistically, there were no significant differences were observed in pigment values as results for using fungus or insect.
The level of photosynthetic pigment like chlorophyll and carotenoids contents of plant in response to the insect attack is mainly determined by the species of host plant and scale of insect abundance. However it can also get influenced with respect to the environmental factors (Mary et al. 2006). The changes in the chlorophyll content in the stress leaves due to less synthesis might be part of adaptive response of plant (Golawska $\boldsymbol{e t}$ al. 2010).

Effect of endophytic $B$. bassiana inoculation and mealy bug infestation on protein concentration

Data in Table (3) indicated that, fungus inoculation caused accumulation of total proteins in 
cotton plants, where spraying and watering treatments were $30.36 \%$ and $26.16 \%$ respectively compared with non-treated plant $(22.73 \%)$.
Statistically, there were significant differences between fungus inoculation and control treatment and within inoculation methods where, $\mathrm{LSD}=1.13$.

Table (2) Chlorophyll a \& b and Carotenoids affected by mealy bug infestation and B. bassiana inoculation

\begin{tabular}{|c|c|c|c|c|c|c|}
\hline & & Control & Spraying & Watering & Pest infestation & F\&LSD \\
\hline \multirow{2}{*}{ Chlorophyll a } & Infested & 1.853 & 1.541 & 1.616 & 1.67 & \multirow{2}{*}{$0.08 \& 0.31$} \\
\hline & Un-infested & 1.872 & 1.688 & 1.759 & 1.773 & \\
\hline \multicolumn{2}{|c|}{ Fungus inoculation } & 1.863 & 1.614 & 1.668 & \multirow{2}{*}{\multicolumn{2}{|c|}{$0.08 \& 0.54$}} \\
\hline \multicolumn{2}{|c|}{ F \& LSD } & \multicolumn{3}{|c|}{$0.96 \& 0.38$} & & \\
\hline \multirow{2}{*}{ Chlorophyll b } & Infested & 0.801 & 0.700 & 0.709 & 0.737 & \multirow{2}{*}{$0.001 \& 0.17$} \\
\hline & Un-infested & 0.658 & 0.801 & 0.741 & 0.733 & \\
\hline \multirow{2}{*}{\multicolumn{2}{|c|}{$\begin{array}{l}\text { Fungus inoculation } \\
\text { F \& LSD } \\
\end{array}$}} & 0.703 & 0.751 & 0.725 & \multirow{2}{*}{\multicolumn{2}{|c|}{$0.78 \& 0.78$}} \\
\hline & & \multicolumn{3}{|c|}{$0.04 \& 0.21$} & & \\
\hline \multirow{2}{*}{ Carotenoids } & Infested & 0.293 & 0.286 & 0.333 & 0.304 & \multirow{2}{*}{$2.018 \& 0.05$} \\
\hline & Un-infested & 0.337 & 0.350 & 0.327 & 0.338 & \\
\hline \multicolumn{2}{|c|}{ Fungus inoculation } & 0.315 & 0.318 & 0.330 & \multirow{2}{*}{\multicolumn{2}{|c|}{$0.76 \&$}} \\
\hline \multicolumn{2}{|c|}{ F \& LSD } & \multicolumn{3}{|c|}{$0.14 \& 0.06$} & & \\
\hline
\end{tabular}

Table (3) Protein concentration affected by mealy bug infestation and B. bassiana inoculation

\begin{tabular}{|l|l|c|c|c|c|c|}
\hline \multicolumn{2}{|l|}{} & Control & Spraying & Watering & Pest infestation & F\&LSD \\
\hline \multirow{2}{*}{$\begin{array}{l}\text { Protein } \\
\text { (conc. \%) }\end{array}$} & Infested & 22.73 & 30.36 & 26.16 & 26.417 & \multirow{2}{*}{0.99} \\
\cline { 2 - 6 } & Un-infested & 26.52 & 27.36 & 32.78 & 28.887 & \\
\hline Fungus inoculation & 24.63 & 28.86 & 29.47 & \multicolumn{2}{|c|}{0.74} \\
\hline F \& LSD & \multicolumn{3}{|c|}{1.13} & \multicolumn{2}{|c|}{} \\
\hline
\end{tabular}

Pest infestation also was recorded significant decrease in protein concentration $26.417 \%$ comparing with un-infest treatment $(28.886 \%)$. The effect of interaction between fungus inoculations and pest infestation were recorded insignificant differences among them.

Protein synthesis is essential for normal cell differentiation and growth. A variety of environmental stressors have been reported to influence the synthesis of plant proteins (William 1989). Plants responded to pathogen attack by formation of new families of proteins called pathogenesis-related proteins or PR proteins (van Loon 1985). Applying of $B$. bassiana to cotton leaves caused prominent accumulation of total proteins. Formation of new proteins and protein accumulation is may be considered a way and an indicator of resistance towards fungus inoculation.
Like the same way of formation of new protein and protein accumulation as a result to virus infestation (Radwan et al. 2010).

\section{Effect of endophytic $B$. bassiana inoculation and mealy bug infestation on Flavonoids and Anti-Oxidants}

Flavonoids and Anti-oxidants values were decreased from 52.98 to 38.6 and $38 \mu \mathrm{g} \mathrm{QE} / \mathrm{mg} \mathrm{d}$ w. (Insignificantly) and from 78.91 to 71.88 and 71.88 DPPH Scavenging ability \% (Significantly), due to applying B. bassiana on leaves (spray) and on roots (watering) of un-infested cotton plants respectively (Table 4). Data in the same table showed insignificantly increase in flavonoids in watering treatment on infested plants, where antioxidants were decreased significantly comparing 
with inoculated plants and among inoculation methods in infested plants.

In general, pest infestation with mealy bug resulted in increased flavonoids from 43.19 to 48.6 $\mu \mathrm{g}$ QE/mg d w., but anti-oxidants were decreased from 74.22 to 73.14 DPPH Scavenging ability \%. Also, fungus inoculations resulted in increased flavonoids insignificantly from $45.72 \mu \mathrm{g}$ QE/mg d w. in non-treated plants to $59.63 \mu \mathrm{g} \mathrm{QE} / \mathrm{mg} \mathrm{d} \mathrm{w}$. in watering plant and decreased in spraying plants to $40.72 \mu \mathrm{g} \mathrm{QE} / \mathrm{mg} \mathrm{d}$ w., where anti-oxidants affected significantly by fungus inoculation methods.

Flavonoids mainly act as antioxidants, to prevent the pest penetration into cells, and to trigger the host cell self-defense mechanisms (Friedman 2007). This supports a role of watering of $B$. bassiana in the induction of antioxidants and enhanced resistance.

Table (4) Flavonoids and Anti-Oxidants affected by mealy bug infestation and B. bassiana inoculation

\begin{tabular}{|c|c|c|c|c|c|c|}
\hline & & Control & Spraying & Watering & Pest infestation & F\&LSD \\
\hline \multirow{2}{*}{ Flavonoids } & Infested & 45.72 & 40.72 & 59.36 & 48.6 & \multirow{2}{*}{$0.68 \& 12.66$} \\
\hline & Un-infested & 52.98 & 38.6 & 38 & 43.19 & \\
\hline \multicolumn{2}{|c|}{ Fungus inoculation } & 49.348 & 39.66 & 48.681 & \multirow{2}{*}{\multicolumn{2}{|c|}{$2.002 \& 21.93$}} \\
\hline \multicolumn{2}{|c|}{ F \& LSD } & \multicolumn{3}{|c|}{$1.05 \& 15.51$} & & \\
\hline \multirow{2}{*}{ Anti-Oxidants } & Infested & 79.11 & 66.21 & 74.11 & 73.15 & \multirow{2}{*}{$5.82 \& 17.5$} \\
\hline & Un-infested & 78.91 & 71.88 & 71.88 & 74.22 & \\
\hline \multicolumn{2}{|c|}{ Fungus inoculation } & 79.012 & 69.045 & 72.994 & \multirow{2}{*}{\multicolumn{2}{|c|}{$1.79 \& 30.31$}} \\
\hline \multicolumn{2}{|l|}{ F \& LSD } & \multicolumn{3}{|c|}{$1.38 \& 21.44$} & & \\
\hline
\end{tabular}

\section{CONCLUSION}

The inoculation with $B$. bassiana in general, led to a significantly increase on average stem length for spray and watering treatments compared with non-treated. Fresh root length was increased significantly in watering treatment and insignificantly with spraying treatment compared with control treatment. Also data revealed that, there were no significant differences observed in pigment values as results for using fungus or insect. While, fungus inoculation caused accumulation of total proteins in cotton plants compared with nontreated plant. Pest infestation also was recorded significant decrease in protein concentration comparing with un-infest treatment. Applying of $B$. bassiana to cotton leaves caused prominent accumulation of total proteins. In general, pest infestation resulted in increased flavonoids, but anti-oxidants were decreased. Also, fungus inoculations resulted in increased flavonoids and decreased in spraying. This supports a role of watering of $B$. bassiana in the induction of antioxidants and enhanced resistance.

\section{REFERENCE}

Arif M. I., Rafiq M., Wazir S., Mehmood N., and Ghaffar (2012). A Studies on cotton mealy bug, Phenacoccus solenopsis (Pseudococcidae: Homoptera), and its natural enemies in Punjab, Pakistan. International Journal of Agriculture and Biology, 14: 557562 .

Azeez 1., Adeoye M. D., Majolagbe T. A., Lawal A. T. and Badiru R. (2012). Antioxidant activity and phytochemical contents of some selected Nigerian fruits and vegetables. American Journal of chemistry, 2(4): 209-213

Bhaigyabati T., Devi P. G. and Bag G. C. (2014).Total flavonoid content and antioxidant activity of aqueous rhizome extract of three Hedychium Species of Manipur Valley. Research Journal of Pharmaceutical Biological and Chemical Sciences, 5(5): 970-976. 
Bills G. F. and Polishook J. D. (1991). Microfungi from Carpinus caroliniana. Canadian Journal of Botany, 69: 1477-1482.

Brownbridge M., Reay S. D., Nelson T. L. and Glare T. R. (2012). Persistence of Beauveria bassiana (Ascomycota: Hypocreales) as an endophyte following inoculation of radiata pine seed and seedlings. Biological Control 61: 194-200.

Cherry A., Lomer C., Djegui D. and Schulthess F. (1999). Pathogen incidence and their potential as microbial control agents in IPM of Maize stem borers in West Africa. Biological control, 44: 301-327.

Culik M. P. and Gullan P. J., (2005). A new pest of tomato and other records of mealy bugs (Hemiptera: Pseudococcidae) from Esperito Santo, Brazil. Zootaxa, 964: 1-8.

Friedman M., (2007). Overview of antibacterial, antitoxin, antiviral, and antifungal activities of tea flavonoids and teas. Molecular Nutrition \& Food Research, 5(1):116-134.

Golawska S., Krzy, Zanowski R. and Lukasik I. (2010). Relationship between infestation and chlorophyll content in Fabaceae species. Acta Biologica Cracoviensia Series Botanica, 52: 76-80.

Greenfield M., Gómez-Jiménez M. I., Ortiz V., Vega F. E., Kramer M. and Parsa S. (2016). Beauveria bassiana and Metarhizium anisopliae endophytically colonize cassava roots following soil drench inoculation. Biological Control 95: 40-48.

Gurulingappa P., Sword G. A., Murdoch G. and Megee P. A. (2010). Colonization of crop plants by fungal entomopathogens and their effects on two insect pests when in planta. Biological Control, 55: 34-41.

Hardoim P.R., Van Overbeek L. S., Berg G., Pirttilä A. M., Compant S. and Campisano A. (2015). The hidden world within plants: ecological and evolutionary considerations for defining functioning of microbial endophytes.
Microbiology and Molecular Biology Reviews, 79: 293-320.

Hegazy A. E. and Ibrahim M. I. (2012). Antioxidant activities of Orange Peel extracts. World Applied Sciences Journal, 18(5): 684688.

Kim J. J., Goettel M. S. and Gillespie, D.R. (2007). Potential of Lecanicillium species for dual microbial control of aphids and the cucumber powdery mildew fungus, Sphaerotheca fuliginea. Biological Control 40: 327-332.

Kim J. J., Goettel M. S. and Gillespie D. R., (2008). Evaluation of Lecanicillium longisporum, Vertalec ${ }^{\circledR}$ for simultaneous suppression of cotton aphid, Aphis gossypii, and cucumber powdery mildew, Sphaerotheca fuliginea, on potted cucumbers. Biological Control 45: 404-409.

Lichtenthaler H. K. (1987). Chlorophylls and carotenoids: pigments of photosynthetic biomemranes. Methods in Enzymology, 148: 350-382.

Lowry O. H., Rosebrough A. L., Fan A. L. and Randall R. J., (1951). Protein measurement with the folin phenol reagent. Journal of Biological Chemistry, 193: 265-275.

Martinuz A., Schouten A. and Sikora R., (2012). Systemically induced resistance and microbial competitive exclusion: implications on biological control. Phytopathology 102: 260266.

Mary E. P., Maria R. and Paymon A. (2006). Response of photosynthesis to high light and drought for Arabidopsis thaliana grown under a UV-B enhanced light regime. Photosynthesis Research, 90:79-90.

Noureen N., Hussain M., Fatima S. and Ghazanfar M., (2016). Cotton Mealy bug Management: A Review. Journal of Entomology and Zoology Studies, 4(4): 657-663.

Orole O. and Adejumo T. (2009). Activity of fungal endophytes against four maize wilt 
pathogens. African Journal of Microbiological Research, 3: 969-973.

Ownley B. H., Griffin M. R., Klingeman W. E., Gwinn K. D., Moulton J. K. and Pereira R. M., (2008). Beauveria bassiana: Endophytic colonization and plant disease control. Journal of Invery. Pathology, 98: 267-270.

Parsa S., Ortiz V. and Vega F. E., (2013). Establishing fungal entomopathogens as endophytes: towards endophytic biological control. Journal of Visualized Experiments, 74: 50360 .

Porras-Alfaro A. and Bayman P., (2011). Hidden fungi, emergent properties: endophytes and microbes. Annual Review Phytopathology, 49: 291-315.

Puri A., Padda K. P. and Chanway C. P., (2016). Evidence of nitrogen fixation and growth promotion in canola (Brassica napus L.) by an endophytic diazotroph Paenibacillus polymyxa P2b-2R. Biology and Fertility of Soils 52: $119-125$.

Qayyum M. A., Wakil W., Arif M. J., Sahi S. T. and Dunlap C. A., (2015). Infection of Helicoverpa armigera by endophytic Beauveria bassiana colonizing tomato plants. Biological Control, 90: 200-207.

Quesada-Moraga E., Munoz-Ledesma F. and Santiago-Alvarez C., (2009). Systemic protection of Papaver somniferum L. against Iraella luteipes (Hymenoptera: Cynipidae) by an endophytic strain of Beauveria bassiana (Ascomycota: Hypocreales). Environmental Entomology, 38: 723-730.

Radwan D. E. M., Fayez K. A., Mahmoud S. Y., and $\mathrm{Lu}$ G., (2010). Modifications of antioxidant activity and protein composition of bean leaf due to Bean yellow mosaic virus infection and salicylic acid treatments. Acta Physiologiae Plantarum, 32: 891-904.
Rodriguez R. J., White J. F., Arnold A. E., and Redman R. S., (2009). Fungal endophytes: diversity and functional roles. New Pathologist, 182: 314-330.

Roy H. E., Steinkraus D. C., Eilenberg J., Hajek A. E. and Pell J. K., (2006). Bizarre interactions and endgames: Entomopathogenic Fungi and Their Arthropod Hosts. Annual Review of Entomology, 51: 331-357.

Shimada K., Fujikawa K., Yahara K. and Nakamura T., (1992). Antioxidative properties of xanthan on the autoxidation of soybean oil in cyclodextrin emulsion. Journal of Agricultural and Food Chemistry, 40: 945948.

Surendra K. Dara, Sumanth S. R. Dara and Suchitra S. Dara, (2017). Impact of Entomopathogenic Fungi on the Growth, Development, and Health of Cabbage Growing under Water Stress. American Journal of Plant Sciences 8: 1224-1233

Van Loon L. C., (1985). Pathogenesis related proteins. Plant Molecular Biology. 4: 111116.

Vega F. E., Posada F., Aime M. C., Pava-Ripoll M., Infante F. and Rehner S. A., (2008). Entomopathogenic fungal endophytes. Biological Control, 46: 72-82.

William A., (1989). The effect of cell cycle regulators on protein profiles in cultured root meristems of Pesium sativum. Environmental and Experimental Botany, 29(3): 317-322

Yong J., Jia-Yu Z., Jia-Xi H., Wei D., Yuan-Qing B., Chang-Hong L., Chuan-Chao D., ( 2013). Distribution of the Entomopathogenic Fungus Beauveria bassiana in Rice Ecosystems and Its Effect on Soil Enzymes. Current Microbiology, 67: 631-636. 